\title{
Automotive shredder residue (ASR): a rapidly increasing waste stream waiting for a sustainable response
}

\author{
V. J. Inglezakis ${ }^{1} \&$ A. A. Zorpas ${ }^{2}$ \\ ${ }^{I}$ SC European Focus Consulting SRL, Romania \\ ${ }^{2}$ EnviTech (Institute of Environmental Technology \& Sustainable \\ Development), Cyprus
}

\begin{abstract}
Recycling scrapped cars plays an important role in reducing pollution by decreasing the amount of waste that ends up in landfills. Directive 2000/53/EC regulates the management of End of Life Vehicles (ELVs). ELVs are collected and dismantled to remove the battery, tyres, fluids and any parts that can be re-used and the wreck is shredded. The metallic parts are separated by physical processes and recovered as ferrous scrap and nonferrous metals, all of which is recycled. The $25 \%$ remainder is the automotive shredder residue (ASR), which is composed mainly of plastics, contaminated with any metallic and other parts that could not be separated. This is often disposed of in landfills as solid urban waste and is not recycled. ASR generation in the EU is approximately 2-2.5 million tonnes/year, constituting $10 \%$ of the total hazardous waste in the EU. The study suggests that recovery rates for ELVs set in the EU Directive on end of life vehicles will not be met until the volume of the ASR is further reduced. Treatment of the ASR focuses on recovering any useable materials, reducing the volume of the ASR to cut down on the quantity that will end up in landfill, and recovering the energy from the petrochemical content of the plastics. Up-to-date there are eight post-shredder technologies (PST) used or potentially used for the treatment of ASR. The aim of this study is to give an overview of what problem the ASR presents to modern society and what the options are for processing this waste into recovered products or materials, or energy, with a minimum of useless by-products for which landfilling is the only route.
\end{abstract}

Keywords: ELVs, ASR, tires, directive 2000/53. 


\section{Introduction}

The generation of End of Life Vehicles (ELVs) is considered as a significant environmental issue due to the large amount and volume of this waste stream, the complexity of their composition, as well as the presence of hazardous materials. The European Commission considers ELVs as priority waste stream according to the European Union (EU) policy and it is expected that ELV quantities will be growing rapidly in the coming years. The entire cycle of a vehicle from its production to its management as an ELV is presented in fig. 1.

The ELV Directive 2000/53 aiming at their sustainable management by setting specific recovery/recycling targets and introducing prevention, collection and treatment procedures is the main legislative tool for ELV management [2].

Recycling scrapped cars plays an important role in reducing pollution by decreasing the amount of waste that ends up in landfills. ELVs are collected and dismantled to remove the battery, tyres, fluids and any parts that can be re-used and the wreck is shredded (fig. 2). The metallic parts are separated by physical processes and recovered as ferrous scrap and nonferrous metals, all of which is recycled. The $25 \%$ remainder is the automotive shredder residue (ASR), which is composed mainly of plastics, contaminated with any metallic and other parts that could not be separated. Overall during shredding, the three basic streams thus generated are:

Ferrous metal (iron and steel) -65 to $70 \%$ by weight.

- Non-ferrous metal (aluminium, stainless steel, copper, brass, lead, magnesium, zinc, and nickel) -5 to $10 \%$ by weight.

- Auto Shredder Residue (ASR or "fluff", consisting of "other materials plastics, glass, rubber, foam, carpeting, textiles, etc.) -20 to $25 \%$ by weight.

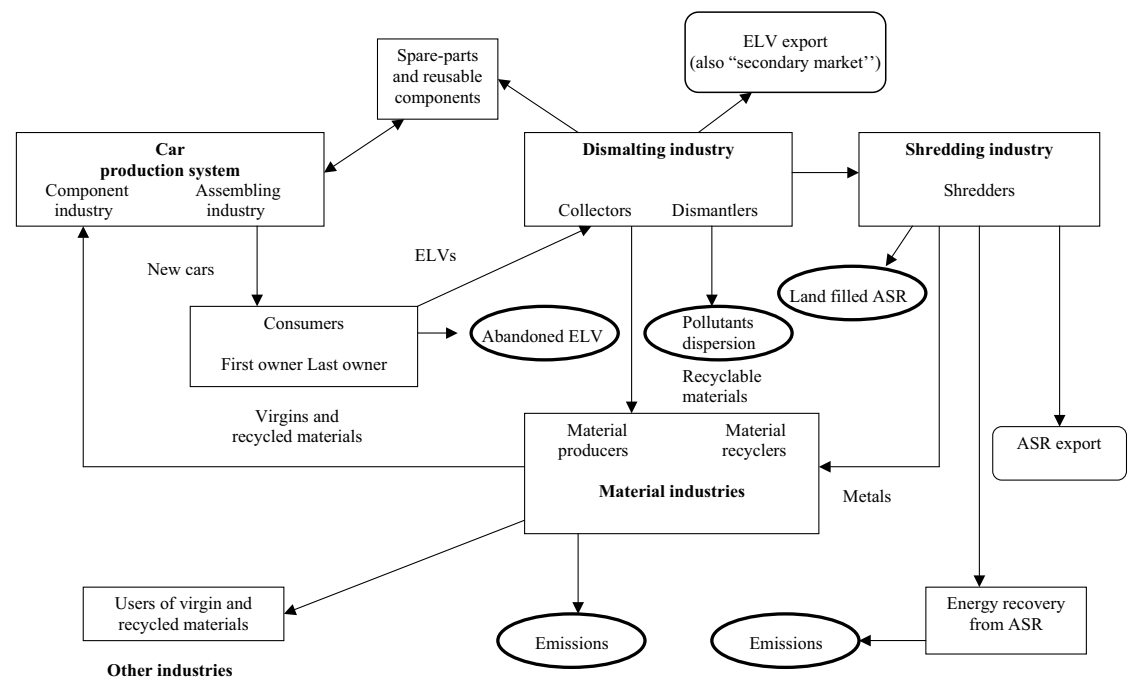

Figure 1: The entire cycle of ELV generation and management [1]. 


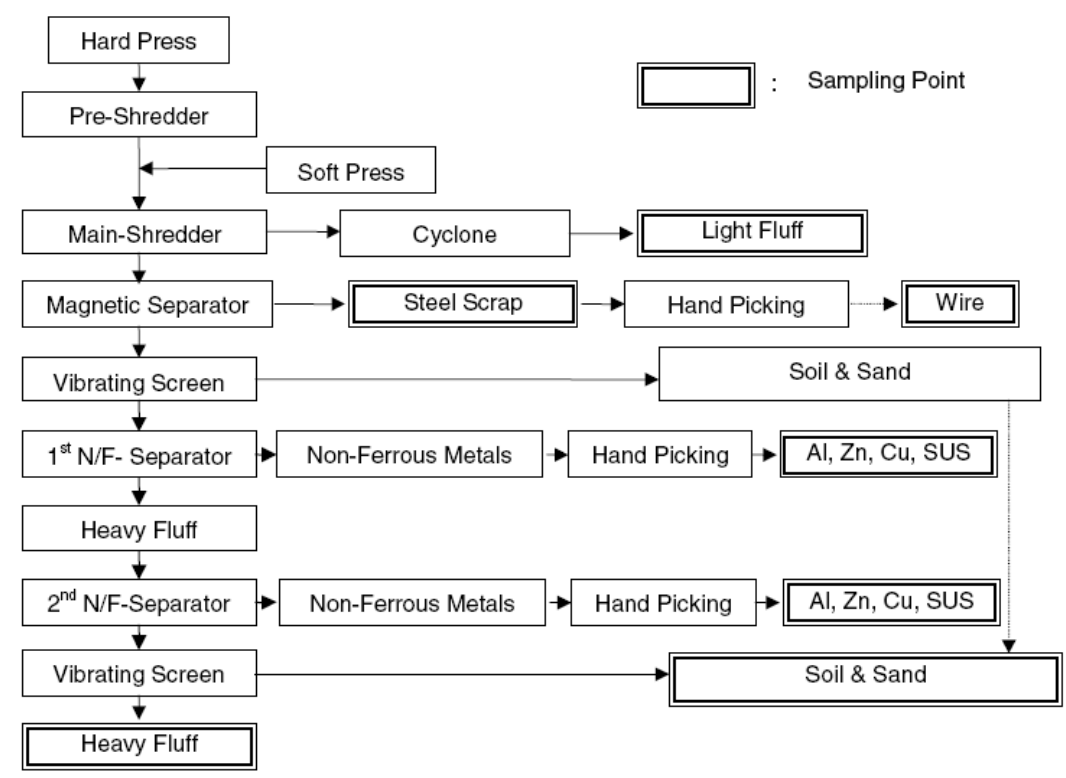

Figure 2: $\quad$ Flow diagram of shredding process [4].

Treatment of the ASR focuses on recovering any useable materials, reducing the volume of the ASR to cut down on the quantity that will end up in landfill, and recovering the energy from the petrochemical content of the plastics. As the target set by the Directive 2000/53 is $95 \%$ of the ELV being reused/recovered, the utilization of ASR is critical as this target will not be met until the volume of ASR is further reduced.

\section{The identity of automotive shredder residue}

There are technical, legislative, commercial and financial drivers affecting the landscape for ASR options, and all of these interact. In different countries these have different overall balances and effects. In California SR has been deemed to be hazardous waste with heavy financial consequences. In Japan, where landfill is running out but the related industries and the government work closely together, thermal processes have already been developed to commercial and semi-commercial stages to treat SR.

Generated ASR contains the bulk of non-metallic materials present in shredder hulks (plastics, glass, rubber, foam, carpeting, textiles, etc), entrained metallic fines, dirt and moisture (see fig. 2). Two types of ASR streams can be generated from overall ELV processing [3]:

- "Light" ASR ("fluff"): Generated at the shredder facility when the nonferrous fraction is separated into metal and non-metallic streams using air classification processes (the non-metallic fraction being "fluff"). It counts for more than $80 \%$ of the total ASR. 
- "Heavy" ASR: Generated at the non-ferrous metal processing facility during separation of the various metal steams (the heavy ASR representing rejected contaminants extracted during processing). It counts for less than $20 \%$ of the total ASR.

Both types of ASR contain similar materials, just in different proportions (light ASR containing a larger proportion of lighter materials like plastic and rubber; heavy ASR containing a larger proportion of heavier materials like glass and metal fines). Auto shredder residue (ASR), also referred to as auto shredder fluff, shedder light fraction (SLF), residues from shredding (RESH) or simply "auto fluff" of "fluff", is the fraction of an shredded end-of-life vehicle (ELV) for which recycling routes are not yet enough developed. The ELV directive mentions 8-9 million tonnes of waste generated by ELVs within the community annually, which suggests an amount of 2-2.5 million tonnes ASR/year, constituting $10 \%$ of total hazardous waste in the EU.

ASR is an extremely inhomogeneous mixture of very different fractions such as plastics, metals, fibres and a lot of sand and dirt. A typical composition of Automotive Shredder Residue (ASR) is presented in Table 1.

The largest fraction are plastics, which are mainly poly olefins (PE, PP), PVC, PU (foam and rigid) nylon (poly amides, PA), poly styrene (PS) and several "blends" such as ABS (acrylonitrile-butadiene-styrene) and glass-fibre enforced polymers. The large PVC content (that can be up to $20 \%$-wt in some ASRs) will put restrictions on thermal processing of ASR for reasons of equipment corrosion risks by $\mathrm{HCl}$, chlorine $\left(\mathrm{Cl}_{2}\right)$ and other chlorinated compounds, formation for dioxins/furans $(\mathrm{PCCD} / \mathrm{Fs})$, or a lower quality of products such as pyrolysis oils [5].

Problematic compounds in ASR that often leads to its classification as hazardous waste are PCBs. After PVC/chlorine and PCBs a third problematic ASR fraction are the trace elements and heavy metals. For all metals, except mercury $(\mathrm{Hg})$ and cadmium $(\mathrm{Cd})$, the concentration levels are about 10 times higher than in municipal solid waste (MSW) [5].

\section{Current options for automotive shredder residue management}

During the 1970s, two methods of shredder residue disposal were practiced: landfilling and incineration. Landfilling continues to be, by far, the most widely practiced technique for disposing of shredder residue. However, the disposal of shredder residue in landfills is already cost-prohibitive in parts of the world or banned altogether. In the United States, some states require that shredder residue be treated to fix and immobilize heavy metals before its disposal in landfills. Because the disposal costs of and environmental concerns over shredder residue are expected to continue to escalate, more economical and environmentally acceptable alternatives are needed. Although many alternatives have been researched (e.g. physical separation, incineration, pyrolysis and composite materials), it seems that the landfilling of ASR still is considered to be is the most appropriate option in the most of the countries. However, landfilling ASR 
is a serious environmental problem. In the 1990s this became an environmental impact issue in Western European countries. In particular, Germany became known world-wide for its approach, requiring the implementation of 'extended producer responsibility' regulation as a solution to post-consumption waste problems. Shredder waste contains from $5 \%$ to $20 \%$ recoverable polymer content (see fig.3). It has to be at least $10 \%$ for recycling to be economical [6]. If only cars are shredded, recoverable polymer content will be around $20 \%$. Two options are generally considered for the ASR: recycling (mainly plastics)/recovery (energy production) and waste disposal.

Table 1: $\quad$ Typical composition of ASR [3].

\begin{tabular}{|l|l|}
\hline Plastics & $31 \%$ \\
\hline Dirt and Metal Fines & $20 \%$ \\
\hline Moisture & $15 \%$ \\
\hline Other Materials (mostly carpeting and textiles) & $13 \%$ \\
\hline Glass & $12 \%$ \\
\hline Rubber & $8 \%$ \\
\hline
\end{tabular}

Because approximately $40-50 \%$ of the shredder residue is hydrocarbon-based materials (such as plastics, fibres, wood, paper, tar, oils, and rubber), the amount that needs to be disposed of can be reduced significantly by [7]:

$\checkmark$ Separation and recovery of recyclable materials from the shredder residue, such as plastics and rubber.

$\checkmark$ Incineration with or without heat recovery. The heating value of shredder residue varies from about 4,000 to $6,000 \mathrm{Btu} / \mathrm{lb}$ and averages approximately $5,400 \mathrm{Btu} / \mathrm{lb}$.

$\checkmark$ Conversion to liquid and gaseous fuels via pyrolysis or gasification of its organic content.

The non-combustible fraction, which contains glass, dirt, rocks, sand, moisture, and residual metals and metal oxides, can also be reduced by separating and recovering the metals and their oxides and maybe the glass. The first commercial ASR recycling plants are only recently developed. An example is the recycling unit of the Galloo Group in Halluin, France. Galloo's recycling process currently yields mostly PP compounds, plus some PS and ABS. Galloo plans to add nylon and PVC separation over the next two years [6].

Up-to-date there are 8 post-shredder technologies (PST) used or potentially used for the treatment of auto shredder residues (ASR). In summary there are two main categories of technology, those based on mechanical sorting of the waste into different fractions that can be recycled and sold; and those based on thermal treatment of the waste stream to generate feedstocks for energy generation. However, with the exception of one or two technologies all the other PSTs are in development, with some technologies already operating at industrial scale (Galloo, Sult, R-Plus, Twin-Rec). The future fate of ASR landfilling will depend on its biodegradability, whether it (or the by-products of ASR processing) is categorised as hazardous waste, and whether it makes up a small or large part of wastes that are landfilled. 
The approximate costs (2006) per tonne ASR for mechanical separation range from as low as 20 to $100 €$, for thermal treatment range from 75 to $200 €$, landfill disposal costs range from 30 to $100 €$ while charges for waste incineration in Germany are $70-300 €$. For new plants costs of $€ 100 € /$ tonne are regarded as realistic.

\section{Overview of post shredder technologies}

This section provides the basic information concerning the schemes/systems that could be applied for the ASR management. The alternative management systems for the treatment of ELVs are presented in fig. 3.

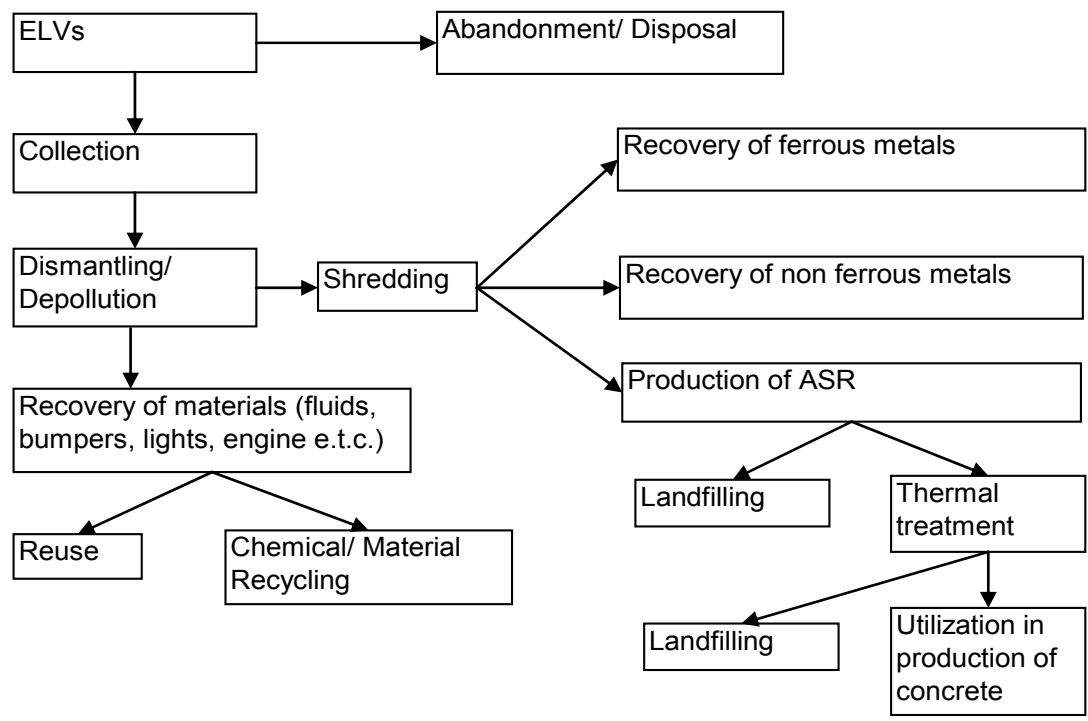

Figure 3: Alternative management practices of ELVs.

In summary there are two main categories of technology, those based on mechanical sorting of the waste into different fractions that can be recycled and sold; and those based on thermal treatment of the waste stream to generate feedstocks for energy generation (Table 2). With the exception of Reshment all the other PSTs are in development, with some technologies already operating at industrial scale (Galloo, Sult, R-Plus, Twin-Rec). Some of the processes described (VW-Sicon, TwinRec, Reshment) are technologies which are licensed to operators. Other technologies (Citron, Galloo, Sult and R-Plus) are developed and operated by the company which owns it.

The information suggests that PSTs range in their reported effectiveness in terms of the overall rates of recycling and recovery of material treated from around $50 \%$ (Galloo and Citron) to $100 \%$ (Sult and R-Plus). In terms of recycling, the reported effectiveness of mechanical separation technologies 
Table 2: $\quad$ Overview of PSTs [8].

\begin{tabular}{|c|c|c|c|c|c|}
\hline $\begin{array}{c}\text { Name of } \\
\text { Technology / } \\
\text { Developer }\end{array}$ & $\begin{array}{c}\text { Type of } \\
\text { Technology }\end{array}$ & $\begin{array}{c}\text { Level of } \\
\text { Technology } \\
\text { Development }\end{array}$ & $\begin{array}{l}\text { Approximate } \\
\text { Outputs from } \\
\text { Process }\end{array}$ & $\begin{array}{l}\text { Overall } \\
\text { Rate of } \\
\text { RRR \% }\end{array}$ & $\begin{array}{c}\text { Recycling } \\
\text { Rate RR \% }\end{array}$ \\
\hline VW - Sicon & $\begin{array}{l}\text { Mechanical } \\
\text { Separation }\end{array}$ & $\begin{array}{l}1 \text { trial plant } 8000 \\
\text { t plus } \\
2 \text { under } \\
\text { construction. } \\
\text { Plans for a } \\
100000\end{array}$ & $\begin{array}{c}\text { Shredder granules } \\
36 \% \text {, shredder } \\
\text { fibres } 31 \% \text {, } \\
\text { metals } 8 \% \text {, } \\
\text { wastes } 26 \%\end{array}$ & 74 & 74 \\
\hline Galloo & $\begin{array}{l}\text { Mechanical } \\
\text { Separation }\end{array}$ & Operating plants & $\begin{array}{c}\text { Recycled plastics } \\
9 \% \text {, metals } 30 \% \text {, } \\
\text { refuse derived } \\
\text { fuel } 13 \% \text {, wastes } \\
48 \%\end{array}$ & 52 & 39 \\
\hline Suit & $\begin{array}{l}\text { Mechanical } \\
\text { Separation }\end{array}$ & $\begin{array}{l}\text { Operating plants } \\
\text { in Japan }\end{array}$ & $\begin{array}{c}\text { Organic plastic } \\
50 \% \text {, mineral } \\
20 \% \text {, metals } 10 \% \text {, } \\
\text { water } 20 \%\end{array}$ & 100 & 80 \\
\hline R-Plus & $\begin{array}{l}\text { Mechanical } \\
\text { Separation }\end{array}$ & Operating plants & $\begin{array}{c}\text { Organic fraction } \\
60 \% \text {, metals } 5 \%, \\
\text { minerals } 35 \%\end{array}$ & 100 & 100 \\
\hline \multirow[t]{2}{*}{ Citron } & \multirow[t]{2}{*}{$\begin{array}{l}\text { Thermal } \\
\text { Treatment - } \\
\text { ox reducer }\end{array}$} & \multirow[t]{2}{*}{$\begin{array}{c}1 \text { trial plant } \\
\text { (130000 } t, 12000 \\
\text { ASR). Plans for a } \\
500000 \mathrm{t}(120000 \\
\text { ASR) plant }\end{array}$} & $\begin{array}{c}\text { Current }-\mathrm{Ca} \mathrm{Fe} \\
\text { concentrate } 45 \% \text {, } \\
\text { Zn concentrate } \\
4.3 \% \text {, Hg } 0.7 \% \text {, } \\
\text { wastes } 50 \%\end{array}$ & 50 & 50 \\
\hline & & & $\begin{array}{l}\text { Plan } \mathrm{Ca} F \\
\text { concentrate } 45 \% \text {, } \\
\mathrm{Zn} \mathrm{concentrate} \\
4.3 \%, \mathrm{Hg} 0.7 \% \text {, } \\
\text { recovery } 50 \%\end{array}$ & 100 & 50 \\
\hline TwinRec & $\begin{array}{c}\text { Thermal } \\
\text { Treatment - } \\
\text { gasifier }\end{array}$ & $\begin{array}{l}\text { Operating plants } \\
\text { in Japan }\end{array}$ & $\begin{array}{l}\text { Metals } 8 \% \text {, glass } \\
\text { granulate } 25 \% \text {, } \\
\text { recovery } 52 \% \text {, } \\
\text { wastes up to } 15 \%\end{array}$ & 85 & 33 \\
\hline $\begin{array}{c}\text { SVZ } \\
\text { Schwarze } \\
\text { Pumpe } \\
\end{array}$ & $\begin{array}{c}\text { Thermal } \\
\text { Treatment - } \\
\text { gasifier }\end{array}$ & $\begin{array}{c}\text { Industrial trial } \\
\text { plant }\end{array}$ & $\begin{array}{c}\text { Synthetic gas } \\
75 \% \text {, metals } 8 \% \text {, } \\
\text { wastes } 17 \%\end{array}$ & 87 & 8 \\
\hline Reshment & $\begin{array}{l}\text { Mechanical } \\
\text { Separation } \\
\text { Thermal } \\
\text { Treatment }\end{array}$ & $\begin{array}{l}\text { No pilot or trial } \\
\text { plants }\end{array}$ & Not available & $\begin{array}{c}\text { Not } \\
\text { available }\end{array}$ & $\begin{array}{c}\text { Not } \\
\text { available }\end{array}$ \\
\hline
\end{tabular}

ranges from $74 \%$ (Sicon) to $100 \%$ (R-Plus). The thermal treatment processes are also intended to recycle some material, principally the remaining metallic residues. These PSTs achieve recycling rates of between 8\% (Schwarze-Pumpe) and $39 \%$ (Galloo). The planned Citron plant is intended to achieve a recycling rate of $50 \%$ [8].

It should be noted that the PSTs are designed to operate after commercial dismantling and shredding and after depollution. Thus the PSTs are designed to deal with the remaining $20 \%-25 \%$ by weight of the average ELV. The implications for the overall rates of recycling and recovery of the PSTs are 
summarised in Table 3, based on the treatment of the residual 20-25\%. This shows that all the technologies (with the exception of Galloo), based on the information provided, are able (with market and depollution practices) to achieve overall rates of recycling and recovery of $95 \%$ or more.

It also indicates that all the PSTs (with the exception of Schwarze-Pumpe) are able to achieve in excess of the $85 \%$ recycling rate. In the case of thermal treatment plants this is mainly because of the separation and recycling of residual metal fractions. In the case of mechanical separation plants the overall rates are achieved through recycling of all fractions, especially plastics [8].

Table 3: Recycling and recovery rates of ELVs using PSTs with current market and depollution practices [8].

\begin{tabular}{|c|c|c|c|}
\hline $\begin{array}{c}\text { Technology } \\
\text { Developer }\end{array}$ & $\begin{array}{c}\text { Type of } \\
\text { Technology }\end{array}$ & $\begin{array}{c}\text { Overall } \\
\text { Recycling \& } \\
\text { Recovery Rate \% }\end{array}$ & $\begin{array}{c}\text { Recycling Rate } \\
\%\end{array}$ \\
\hline VW - Sicon & $\begin{array}{c}\text { Mechanical } \\
\text { Separation }\end{array}$ & 95 & 95 \\
\hline Galloo & $\begin{array}{c}\text { Mechanical } \\
\text { Separation }\end{array}$ & 90 & 96 \\
\hline Suit & $\begin{array}{c}\text { Mechanical } \\
\text { Separation }\end{array}$ & 100 & 90 \\
\hline R-Plus & $\begin{array}{c}\text { Mechanical } \\
\text { Separation }\end{array}$ & 100 & 87 \\
\hline Citron & $\begin{array}{c}\text { Thermal Treatment }- \\
\text { ox reducer }\end{array}$ & 100 & 82 \\
\hline TwinRec & $\begin{array}{c}\text { Thermal Treatment }- \\
\text { gasifier }\end{array}$ & 97 & 97 \\
\hline $\begin{array}{c}\text { SVZ Schwarze } \\
\text { Pumpe }\end{array}$ & $\begin{array}{c}\text { Thermal Treatment }- \\
\text { gasifier }\end{array}$ & 97 & \\
\hline
\end{tabular}

\section{References}

[1] Zoboli R., Barbiroli G., Leonchini R., Mazzanti M. \& Montresor S. Regulation and innovation in the area of end-of-life vehicles, Report prepared for European Commission JRC-IPTS and Enterprise DG, 2000.

[2] European Commission, Directive 53/2000 of the European Parliament and of the Council of 18 September 2000 on End-of-Life Vehicles, 2000.

[3] Jeff Staudinger \& Gregory A. Keoleian, Management of End-of Life Vehicles (ELVs) in the US, University of Michigan, USA, 2001.

[4] Ki-Heon Kim, Hyun-Tae Joung, Hoon Nam, Yong-Chil Seo, John Hee Hong, Tae-Wook Yoo, Bong-Soo Lim \& Jin-Ho Park, Management status of end-of-life vehicles and characteristics of automobile shredder residues in Korea. Waste Management, 24, 533-540, 2004.

[5] Ron Zevenhoven \& Loay Saeed, Automotive shredder residue (ASR) and compact disc (CD) waste: options for recovery of materials and energy. Helsinki University of Technology, Energy Engineering and Environmental Protection, 2003. 
[6] Close-Up On Recycling How to Turn Auto Shredder Waste Into 60 Million Lb of Plastic Pellets. Plastics Technology, 2008. www.PTOnline.com

[7] B.J. Jody \& E.J. Daniels, End-of-Life Vehicle Recycling: The State of the Art of Resource Recovery from Shredder Residue, Agronne National Laboratory, Energy Systems Division, USA, 2006

[8] GHK in association with Bio Intelligence Service, Study to Examine the Costs and Benefits of the ELV Directive - Final Report Annexes. Annex 3: Post-shredder technologies - review of the technologies and costs, Final Report to DG Environment, 2006. 